\title{
UNG wt Allele
}

National Cancer Institute

\section{Source}

National Cancer Institute. UNG wt Allele. NCI Thesaurus. Code C106307.

Human UNG wild-type allele is located within 12q23-q24.1 and is approximately $13 \mathrm{~kb}$ in length. This allele, which encodes uracil-DNA glycosylase protein, is involved in the removal of uracil from DNA. 